\title{
Anti-bacterial properties of calcium hydroxide in combination with silver, copper, zinc oxide or magnesium oxide
}

\author{
Hazhir Yousefshahi (1), Mohsen Aminsobhani (1), Mehdi Shokri (2), Razieh Shahbazi (2) \\ (1) Dental school, Aja University of Medical Sciences, Tehran, Iran; (2) Department of Dental \\ Biomaterials, Dental School, Shahid Beheshti University of Medical Sciences,Tehran, Iran.
}

This article is distributed under the terms of the Creative Commons Attribution Noncommercial License (CC BY-NC 4.0) which permits any noncommercial use, distribution, and reproduction in any medium, provided the original author(s) and source are credited.

\begin{abstract}
Prevention of bacterial growth among root canal treatment sessions is a prerequisite for successful root canal treatment. The most common way to achieve this is to use calcium hydroxide in the treatment sessions. Some studies have shown calcium hydroxide inefficiency in this field. The aim of this study was to investigate and compare the effects of silver, copper, zinc oxide and magnesium oxide nanoparticles on the inhibitory effects of calcium hydroxide based on Enterococcus faecalis species. Enterococcus faecalis bacteria having 0.5 McFarland concentration were prepared. Plates containing BHI agar medium were prepared. In each plate, four wells were created and the plate was cultured using a sterile swab. Afterwards, calcium hydroxide composition of $1 \%$ and $2 \%$ concentration from silver, copper, zinc oxide and magnesium oxide nanoparticles were prepared separately, as well as the combination of calcium hydroxide with $1 \%$ silver in combination with $1 \%$ of copper, zinc oxide and magnesium oxide nanoparticles, which were then transferred to the wells. After 24 hours of incubation, the inhibition zone diameter was measured. Data were analyzed by Mann-Withney test. At $1 \%$ concentration, only the combination of copper nanoparticles with calcium hydroxide could significantly create an inhibition zone larger than calcium hydroxide alone (P value $<0.5$ ). At $2 \%$ concentration, the combination of copper nanoparticles with calcium hydroxide, and the combination of silver nanoparticles with calcium hydroxide, were significantly higher than calcium hydroxide alone $(\mathrm{P}$ value $<0.5)$. The calcium hydroxide composition containing $1 \%$ silver nanoparticles in combination with $1 \%$ copper, zinc oxide and magnesium oxide nanoparticles significantly increased the growth inhibition zone more than calcium hydroxide alone. (P Value <0.5). Copper nanoparticles showed the best antibacterial properties among silver, copper, magnesium oxide and zinc oxide nanoparticles in combination with calcium hydroxide. Also, the combination of $1 \%$ of nanoparticles with each other increases antibacterial properties.
\end{abstract}

Key Words: Copper, silver, zinc oxide, magnesium oxide, growth inhibition zone, enterococcus faecalis, calcium hydroxide.

Eur J Transl Myol 28 (3): 274-279, 2018

\begin{abstract}
During the root canal treatment process, bacteria in the root canal play an important role in the development, expansion and stability of root lesions. ${ }^{1}$ Considering the complex anatomy of the root canal and the impossibility of mechanical preparation of all root sites to remove bacterial agents, the use of antibacterial agents for root canal removal is recommended. ${ }^{2}$ Even by using these methods, the canal is not completely cleared of bacterial agents. According to Bystrom et al., if the canal remains empty between treatment sessions, the bacteria are replicated and the number of bacteria increases even to the initial number at the onset of treatment. ${ }^{3}$ To overcome this problem, calcium hydroxide has been used extensively to fill the canal between treatment sessions. $^{4,5}$
\end{abstract}

Calcium hydroxide has antibacterial properties. $^{2}$ Although calcium hydroxide is widely used, its application has been questioned in some studies. Some evidence confirm the inactivation of antibacterial activity of calcium hydroxide by dentin and increased bacteria after treatment with calcium hydroxide. ${ }^{6,7}$ Considering the calcium hydroxide weaknesses, efforts have been made to improve the antibacterial properties of calcium hydroxide. Different studies had shown that using Silver or Copper alongside Calcium hydroxide improved Antibacterial properties. ${ }^{8-12}$ Metal oxides have been used for centuries as antibacterial agents. Metal oxides like Zinc Oxide and Magnesium Oxide have antibacterial properties in various forms. ${ }^{13-16}$ It should be kept in mind that the effectiveness of these elements 
depends on their contact surface. Along with technology advancement and the possibility of reducing metal particle sizes from micro to nanoscale and increasing the contact surface of metal particles, it is possible to increase antibacterial properties. ${ }^{17}$ Also, the simultaneous use of antibacterial compounds is a common practice for increasing antibacterial effects. Synergistic effects of antibacterial compounds reduce the need for higher drug doses to limit the side effects. ${ }^{18-}$ 20 According to the above, it seems that the use of calcium hydroxide alone does not eliminate the needs for root canal treatment. On the other hand, considering the antibacterial properties in metallic nanoparticles and the effect of these metals on increasing the antibacterial properties of calcium hydroxide and the lack of comprehensive study to compare the antibacterial properties of these particles in combination with calcium hydroxide, the present study aimed to investigate the antibacterial properties of calcium hydroxide in combination with metal nanoparticles of silver, copper, zinc oxide and magnesium oxide at similar concentrations and in combination with each other compared to calcium hydroxide.

\section{Materials and Methods}

Enterococcus faecalis bacteria were prepared as liofilic vials from the Iranian Pasteur Institute with persian type culture collection (PTCC):1394, and then after pouring into a liquid medium of Brain Heart Infusion Broth (Merck, Darmstadt Germany), it was incubated for 48 hours at $37^{\circ} \mathrm{C}$. It was then cultured on a solid medium of Triptic Soy Agar (Merck, Darmstadt Germany) for 48 hours to create a colony. Then, using these colonies and with the aid of a physiological serum, a suspension was prepared with a concentration of approximately 0.5 McFarland $(1.5 \times 108$ cells / mL). Pure calcium hydroxide powder (Merck, Darmstadt Germany) and nanosized metal particles with $20 \mathrm{~nm}$ dimensions (US Research nanomaterials, Huston, USA) were prepared. For the preparation of calcium hydroxide paste, modified with $1 \%$ silver, copper, zinc oxide and magnesium oxide nanoparticles, $990 \mathrm{mg}$ of calcium hydroxide powder was combined with $1 \mathrm{ml}$ of $10 \mathrm{mg} /$ $\mathrm{ml}$ solution of the mentioned nanoparticles (Table 1). For the preparation of calcium hydroxide paste, modified with $2 \%$ silver, copper, zinc oxide and magnesium oxide nanoparticles, $990 \mathrm{mg}$ of calcium hydroxide powder was combined with $1 \mathrm{ml}$ of $20 \mathrm{mg} /$ $\mathrm{ml}$ solution of the mentioned nanoparticles (Table 1). For the preparation of calcium hydroxide paste, modified with zinc oxide nanoparticles, $980 \mathrm{mg}$ of calcium hydroxide powder was combined with $1 \mathrm{ml}$ of $20 \mathrm{mg} / \mathrm{ml}$ solution of silver and zinc oxide nanoparticles $(10 \mathrm{mg}$ of silver nanoparticles in combination with $10 \mathrm{mg}$ of Zinc oxide nanoparticles) (Table 1). For the preparation of calcium hydroxide paste, modified with silver and copper nanoparticles, $980 \mathrm{mg}$ of calcium hydroxide powder was combined
Table 1. Combination groups

\begin{tabular}{|c|c|c|}
\hline Group & $\mathrm{Ca}(\mathrm{OH})_{2}$ & Nano Particles \\
\hline $\begin{array}{l}\mathrm{Ca}(\mathrm{OH})_{2}+1 \% \\
\mathrm{Ag}\end{array}$ & $990 \mathrm{mg} \mathrm{Ca}(\mathrm{OH})_{2}$ & $\begin{array}{l}1000 \mathrm{ml} \text { of } 10 \\
\mathrm{mg} / \mathrm{ml} \text { Nano } \\
\mathrm{Ag} \text { solution }\end{array}$ \\
\hline $\begin{array}{l}\mathrm{Ca}(\mathrm{OH})_{2}+2 \% \\
\mathrm{Ag}\end{array}$ & $980 \mathrm{mg} \mathrm{Ca}(\mathrm{OH})_{2}$ & $\begin{array}{l}1000 \mathrm{ml} \text { of } 20 \\
\mathrm{mg} / \mathrm{ml} \text { Nano } \\
\mathrm{Ag} \text { solution }\end{array}$ \\
\hline $\begin{array}{l}\mathrm{Ca}(\mathrm{OH})_{2}+1 \% \\
\mathrm{Cu}\end{array}$ & $990 \mathrm{mg} \mathrm{Ca}(\mathrm{OH})_{2}$ & $\begin{array}{l}1000 \mathrm{ml} \text { of } 10 \\
\mathrm{mg} / \mathrm{ml} \text { Nano } \\
\mathrm{Cu} \text { solution }\end{array}$ \\
\hline $\begin{array}{l}\mathrm{Ca}(\mathrm{OH})_{2}+2 \% \\
\mathrm{Cu}\end{array}$ & $980 \mathrm{mg} \mathrm{Ca}(\mathrm{OH})_{2}$ & $\begin{array}{l}1000 \mathrm{ml} \text { of } 20 \\
\mathrm{mg} / \mathrm{ml} \text { Nano } \\
\text { Cu solution }\end{array}$ \\
\hline $\begin{array}{l}\mathrm{Ca}(\mathrm{OH})_{2}+1 \% \\
\mathrm{MgO}\end{array}$ & $990 \mathrm{mg} \mathrm{Ca}(\mathrm{OH})_{2}$ & $\begin{array}{l}1000 \mathrm{ml} \text { of } 10 \\
\mathrm{mg} / \mathrm{ml} \text { Nano } \\
\mathrm{MgO} \text { solution }\end{array}$ \\
\hline $\begin{array}{l}\mathrm{Ca}(\mathrm{OH})_{2}+2 \% \\
\mathrm{MgO}\end{array}$ & $980 \mathrm{mg} \mathrm{Ca}(\mathrm{OH})_{2}$ & $\begin{array}{l}1000 \mathrm{ml} \text { of } 20 \\
\mathrm{mg} / \mathrm{ml} \text { Nano } \\
\mathrm{MgO} \text { solution }\end{array}$ \\
\hline $\begin{array}{l}\mathrm{Ca}(\mathrm{OH})_{2}+1 \% \\
\mathrm{ZnO}\end{array}$ & $990 \mathrm{mg} \mathrm{Ca}(\mathrm{OH})_{2}$ & $\begin{array}{l}1000 \mathrm{ml} \text { of } 10 \\
\mathrm{mg} / \mathrm{ml} \text { Nano } \\
\mathrm{ZnO} \text { solution }\end{array}$ \\
\hline $\begin{array}{l}\mathrm{Ca}(\mathrm{OH})_{2}+2 \% \\
\mathrm{ZnO}\end{array}$ & $980 \mathrm{mg} \mathrm{Ca}(\mathrm{OH})_{2}$ & $\begin{array}{l}1000 \mathrm{ml} \text { of } 20 \\
\mathrm{mg} / \mathrm{ml} \text { Nano } \\
\mathrm{ZnO} \text { solution }\end{array}$ \\
\hline $\begin{array}{l}\mathrm{Ca}(\mathrm{OH})_{2}+2 \% \\
\mathrm{Ag}-\mathrm{ZnO}\end{array}$ & $980 \mathrm{mg} \mathrm{Ca}(\mathrm{OH})_{2}$ & $\begin{array}{ll}1000 \mathrm{ml} \text { of } 20 \\
\mathrm{mg} / \mathrm{ml} & \text { Nano } \\
\mathrm{Ag}-\mathrm{ZnO} & \\
\text { solution } & \\
\end{array}$ \\
\hline $\begin{array}{l}\mathrm{Ca}(\mathrm{OH})_{2}+2 \% \\
\mathrm{Ag}-\mathrm{Cu}\end{array}$ & $980 \mathrm{mg} \mathrm{Ca}(\mathrm{OH})_{2}$ & $\begin{array}{ll}1000 \mathrm{ml} \text { of } 20 \\
\mathrm{mg} / \mathrm{ml} & \text { Nano } \\
\mathrm{Ag}-\mathrm{Cu} & \\
\text { solution } & \\
\end{array}$ \\
\hline $\begin{array}{l}\mathrm{Ca}(\mathrm{OH})_{2}+2 \% \\
\mathrm{Ag}-\mathrm{MgO}\end{array}$ & $980 \mathrm{mg} \mathrm{Ca}(\mathrm{OH})_{2}$ & $\begin{array}{ll}1000 \mathrm{ml} \text { of } 20 \\
\mathrm{mg} / \mathrm{ml} \text { Nano } \\
\mathrm{Ag}-\mathrm{MgO} \\
\text { solution }\end{array}$ \\
\hline $\mathrm{Ca}(\mathrm{OH})_{2}$ & $1000 \mathrm{mg} \mathrm{Ca}(\mathrm{OH})_{2}$ & $\begin{array}{l}1000 \mathrm{ml} \\
\text { distilled water }\end{array}$ \\
\hline $\begin{array}{l}\text { Posetive } \\
\text { Control } \\
\end{array}$ & Chlorhexidine & 0 \\
\hline $\begin{array}{l}\text { Negative } \\
\text { Control } \\
\end{array}$ & - & - \\
\hline
\end{tabular}

with $1 \mathrm{ml}$ of $20 \mathrm{mg} / \mathrm{ml}$ solution of silver and copper nanoparticles $(10 \mathrm{mg}$ of silver nanoparticles in combination with $10 \mathrm{mg}$ of copper nanoparticles) (Table 1). To prepare the calcium hydroxide paste modified with silver and magnesium oxide nanoparticles, $980 \mathrm{mg}$ of calcium hydroxide powder was combined with $1 \mathrm{ml}$ of $20 \mathrm{mg} / \mathrm{ml}$ solution of silver and magnesium oxide nanoparticles $(10 \mathrm{mg}$ of silver nanoparticles in combination with $10 \mathrm{mg}$ of magnesium oxide nanoparticles) (Table 1). $2 \%$ chlorhexidine was used as positive control group and empty cavity as negative control. To prepare the culture medium, brain heart infusion (BHI) is injected into a sterile disposable plate of $10 \mathrm{~cm}$ diameter so that a 5-millimeter thick volume is 


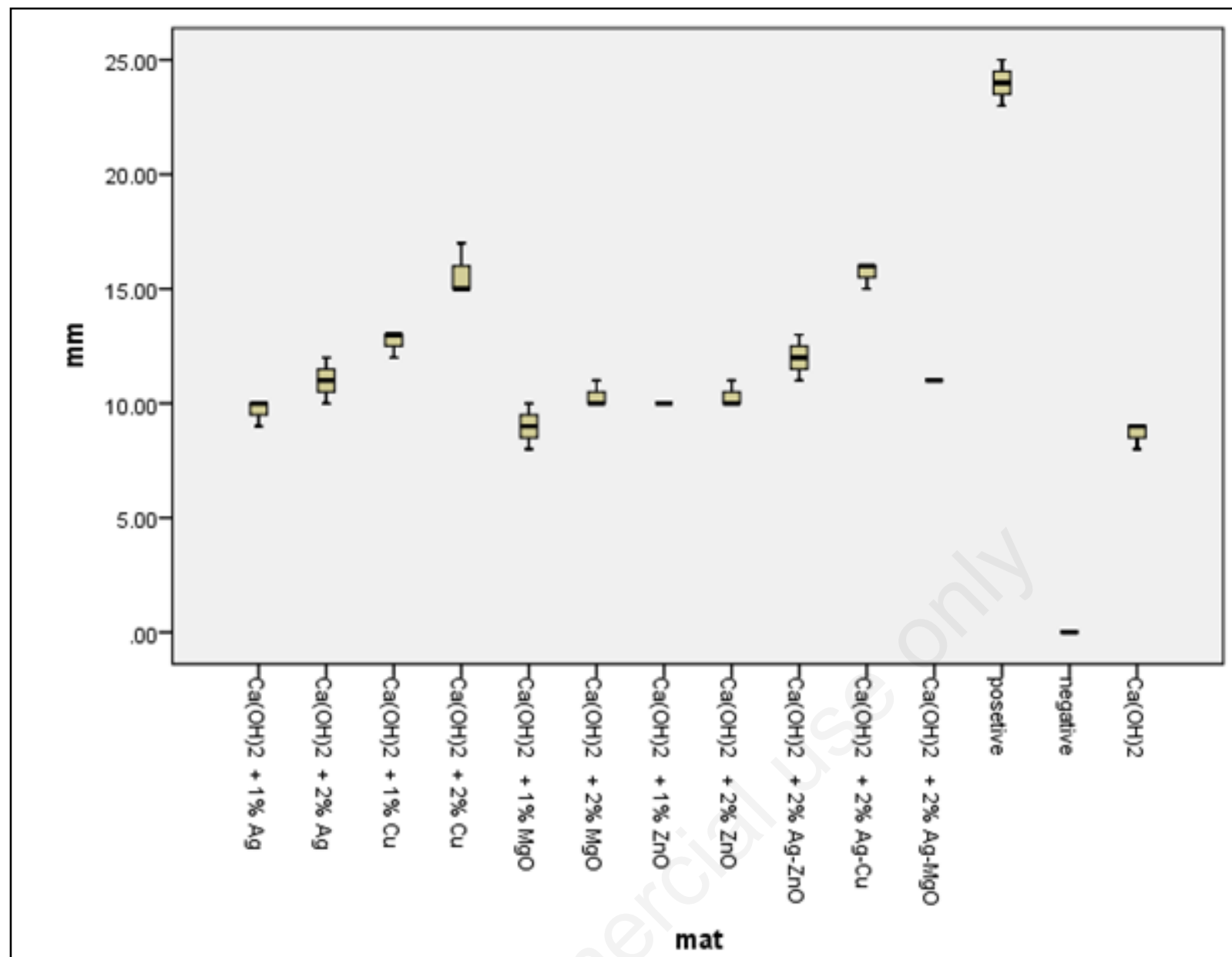

Fig 1. Mean inhibition zone in different groups

created. After cooling the mixture, four cavities with identical intervals of $5 \mathrm{~mm}$ diameter and $5 \mathrm{~mm}$ depth in agar are created in each container using sterile punch. Then, using sterile swabs, culturing was carried out from the bacteria containing solution. The cavities were then filled with specimens. The plate was incubated for 24 hours. After this time, the diameter of the growth inhibitation zone was measured. Data were analyzed by SPSS version 21 software using Kolmogorov-Smirnov and Shapiro-Wilk statistical tests to determine the distribution of normal or abnormal data. Then, based on the test results, in the case of normal distribution, the Tuckey test was used and in the case of abnormal distribution, the Mann-Whitney test was performed.

\section{Results and Discussion}

The mean diameter of the inhibition zone is shown in Figure 1. According to the results, all groups have a higher inhibition zone than calcium hydroxide alone. The statistical results of Kolmogorov-Smirnov and Shapiro-Wilk showed an abnormal data distribution. Therefore, data were analyzed using the Mann-Whitney test.
Based on the statistical results, In $1 \%$ nano metal concentration, inhibition zone diameter for $\mathrm{Ca}(\mathrm{OH})_{2}+$ $1 \% \mathrm{Cu}$ was significantly different with calcium hydroxide alone ( $\mathrm{P}$ value $<0.05)$. based on the statistical analysis for $2 \%$ concentration of Nano metal, there were a significant difference between inhibition zone of $\mathrm{Ca}(\mathrm{OH})_{2}+2 \% \mathrm{Ag}$ and $\mathrm{Ca}(\mathrm{OH})_{2}+2 \% \mathrm{Cu}$ compare to calcium hydroxide alone ( $\mathrm{P}$ value $<0.05)$. In the combination of calcium hydroxide with silver nanoparticles and copper nanoparticles, zinc oxide and magnesium oxide, the inhibition zone diameter of all groups $\left(\mathrm{Ca}(\mathrm{OH})_{2}+2 \% \mathrm{Ag}-\mathrm{ZnO}, \mathrm{Ca}(\mathrm{OH})_{2}+2 \% \mathrm{Ag}-\mathrm{Cu}\right.$, $\left.\mathrm{Ca}(\mathrm{OH})_{2}+2 \% \mathrm{Ag}-\mathrm{MgO}\right)$ had a significant difference with calcium hydroxide alone $(\mathrm{P}$ value $<0.05)$. (Table 2 ). Statistical analysis was performed among groups that had a significantly larger inhibition zone than calcium hydroxide alone. The inhibition zone diameter for $\mathrm{Ca}(\mathrm{OH})_{2}+2 \% \mathrm{Ag}, \mathrm{Ca}(\mathrm{OH})_{2}+1 \% \mathrm{Cu}, \mathrm{Ca}(\mathrm{OH})_{2}+2 \%$ $\mathrm{Ag}-\mathrm{MgO}$ and $\mathrm{Ca}(\mathrm{OH})_{2}+2 \% \mathrm{Ag}-\mathrm{ZnO}$, statistically had no significant difference. The inhibition zone diameter was similar between $\mathrm{Ca}(\mathrm{OH})_{2}+2 \% \mathrm{Ag}-\mathrm{Cu}$ and $\mathrm{Ca}(\mathrm{OH})_{2}+2 \% \mathrm{Cu}$ groups and did not show any significant difference ( $\mathrm{P}$ Value $<0.05$ ). Also, based on the results, the largest inhibition zone was related to 
Table 2. P-values of $\mathrm{Ca}(\mathrm{OH})_{2}$ group compared to other groups

\begin{tabular}{|l|l|}
\hline $\mathrm{Ca}(\mathrm{OH})_{2}+1 \% \mathrm{Ag}$ & 0.90 \\
\hline $\mathrm{Ca}(\mathrm{OH})_{2}+2 \% \mathrm{Ag}$ & 0.02 \\
\hline $\mathrm{Ca}(\mathrm{OH})_{2}+1 \% \mathrm{Cu}$ & 0.00 \\
\hline $\mathrm{Ca}(\mathrm{OH})_{2}+2 \% \mathrm{Cu}$ & 1.00 \\
\hline $\mathrm{Ca}(\mathrm{OH})_{2}+1 \% \mathrm{MgO}$ & 0.27 \\
\hline $\mathrm{Ca}(\mathrm{OH})_{2}+2 \% \mathrm{MgO}$ & 0.59 \\
\hline $\mathrm{Ca}(\mathrm{OH})_{2}+1 \% \mathrm{ZnO}$ & 0.27 \\
\hline $\mathrm{Ca}(\mathrm{OH})_{2}+2 \% \mathrm{ZnO}$ & 0.00 \\
\hline $\mathrm{Ca}(\mathrm{OH})_{2}+2 \% \mathrm{Ag}-\mathrm{ZnO}$ & 0.00 \\
\hline $\mathrm{Ca}(\mathrm{OH})_{2}+2 \% \mathrm{Ag}-\mathrm{Cu}$ & 0.00 \\
\hline $\mathrm{Ca}(\mathrm{OH})_{2}+2 \% \mathrm{Ag}-\mathrm{MgO}$ & 0.00 \\
\hline $\mathrm{Posetive} \mathrm{Control}$ & 0.00 \\
\hline $\mathrm{Negative} \mathrm{Control}$ &
\end{tabular}

$\mathrm{Ca}(\mathrm{OH})_{2}+2 \% \mathrm{Cu}$ and $\mathrm{Ca}(\mathrm{OH})_{2}+2 \% \mathrm{Ag}-\mathrm{Cu}$, which statistically had significantly larger inhibition zone than other study groups ( $\mathrm{P}$ Value $<0.05$ ). According to the results of the present study for the inhibition zone diameter of $1 \%$ concentration of different metal nanoparticles with calcium hydroxide, the diameter of the inhibition zone of calcium hydroxide alone had a significant difference with the $\mathrm{Ca}(\mathrm{OH})_{2}+1 \% \mathrm{Cu}$ group. Based on the statistical analysis of the inhibition zone diameter in $2 \%$ concentration of metal nanoparticles in combination with calcium hydroxide, calcium hydroxide alone had a significant difference with $\mathrm{Ca}(\mathrm{OH})_{2}+2 \% \mathrm{Ag}$ and $\mathrm{Ca}(\mathrm{OH})_{2}+2 \% \mathrm{Cu}$. According to Afkhami et al., The combination of calcium hydroxide paste and silver nanoparticles with 100PPM concentration, significantly improved the antibacterial properties in contrast to calcium hydroxide alone. ${ }^{8}$ According to Samii et al., the use of mineral trioxide aggregate (MTA) containing $1 \%$ silver nanoparticles significantly inhibits the growth of E. faecalis, C. albicans, and P. aeruginosa compared to MTA alone. ${ }^{9}$ Based on the study of Javadi et al., The combination of $10 \%$ calcium hydroxide and 200PPM silver significantly improved the growth inhibition of $\mathrm{E}$. faecalis compared to calcium hydroxide alone in the infected teeth canal. ${ }^{10}$ The results of studies by Fuzz et al. and Knappwost et al. showed that the antibacterial properties of calcium hydroxide and copper combination was superior to calcium hydroxide alone. ${ }^{11,12}$ Based on the results of this study, there was no difference between the $\mathrm{Ca}(\mathrm{OH})_{2}+1 \% \mathrm{MgO}$, $\mathrm{Ca}(\mathrm{OH})_{2}+2 \% \mathrm{MgO}, \mathrm{Ca}(\mathrm{OH})_{2}+1 \% \mathrm{ZnO}, \mathrm{Ca}(\mathrm{OH})_{2}+$ $\% \mathrm{ZnO}$ group and calcium hydroxide alone in case of the inhibition zone diameter. According to Sawai et al., $100 \mathrm{mg} / \mathrm{ml}$ magnesium oxide concentrations have antibacterial effects against Eschrisia coli and Stafilocucus areus. ${ }^{13}$ According to the Jin and He study, nano particles of magnesium oxide at $8 \mathrm{mg} / \mathrm{ml}$ concentration inhibit the growth of Eschrichia coli. ${ }^{14}$ According to the Sawai study, $\mathrm{MgO}$ and $\mathrm{ZnO}$ metal particles have anti-bacterial properties against Staphylococcus aureus and Escherichia coli. ${ }^{15}$ According to a study by Aydin Sevinç et al., the addition of $10 \%$ zinc oxide nanoparticles to the composite reduced the growth of Streptococcus sobrinus to $80 \%$ and the minimum inhibitory concentration of zinc oxide nanoparticles was determined at $50 \mu \mathrm{g} / \mathrm{ml}^{16}$ There are many differences between the effective concentration and the efficacy of different compounds against microorganisms among different studies. This difference may be due to the use of different methods to investigate the alteration of antibacterial properties of materials by nanoparticles. For example, in the present study, the inhibition zone diameter of Entrococus faecalis for calcium hydroxide containing $1 \%$ silver nanoparticles, was significantly different from calcium hydroxide alone. While in another study, the use of a solution containing $10 \%$ calcium hydroxide and 200 PPM of silver in the canal infected with Entrococus faecalis had better antibacterial properties than calcium hydroxide solution. ${ }^{10}$ The effect of nanoparticles on the alteration of antibacterial properties of substances may also be affected by the accompanying material used. For example, in the present study, the inhibition zone diameter of Entrococus faecalis in calcium hydroxide containing $1 \%$ silver did not differ significantly from calcium hydroxide alone. While in another study, the MTA composition containing $1 \%$ silver nanoparticles significantly improved the Entrococu faecalis growth inhibitation, ${ }^{10,21-23}$ better than MTA alone. Also another possible cause for differences in the antibacterial nature is particle size. Different studies have shown an increase in antibacterial properties by reducing particle size. ${ }^{24,25}$ In the present study, for the combination of $1 \%$ nano particles with calcium hydroxide, copper, zinc oxide, silver and magnesium oxide had the highest to lowest inhibition zone diameter, respectively. In the combination of $2 \%$ nano particles with calcium hydroxide, copper, silver and then zinc oxide equal with magnesium oxide, had the highest to lowest inhibition zone diameter, respectively. In the study of Top et al., the results of antimicrobial properties of copper, silver 
and zinc ions in combination with Clinoptilolite showed that the highest antibacterial properties against pseudomonas aeruginosa and escherichia coli were related to the silver compound and the copper was at next place. ${ }^{26}$ According to Du et al., the anti-bacterial properties of Chitosan alone and in combination with silver, copper, zinc, magnesium and iron particles, silver, copper, magnesium and zinc had the highest to lowest antibacterial strength, respectively Combining these particles with Chitosan made it possible to significantly improve the antibacterial properties of chitosan. ${ }^{27}$ According to McLean et al., comparing the antibacterial properties of silver and copper combination on different carriers, results showed higher antibacterial effects for copper than silver. ${ }^{28}$ Contrary to the results of the present study which copper particles had higher antibacterial properties than silver, in studies of $\mathrm{Du}$ et al. and Top et al., silver alone and in combination with other materials had antibacterial properties higher than copper. ${ }^{26,27}$ While the results of the study by McLean et al., similar to the present study, showed better antibacterial properties of copper than silver. ${ }^{28}$ This difference in the amount and strength of antibacterial particles of similar particles in different compounds can be related to the oxidation-reduction state in the composition of metal particles combined with different materials. ${ }^{29}$ Also, the combination of accompanying particles and carrier used may also affect the extent of particle effects. ${ }^{28,30}$ According to the results of this study, the inhibitaion zone diameter of calcium hydroxide composition with $1 \%$ silver nanoparticles was not significantly different from calcium hydroxide alone. By adding $1 \%$ copper, magnesium oxide or zinc oxide nanoparticles to calcium hydroxide containing $1 \%$ silver nanoparticles, the inhibition zone diameter expanded significantly more than calcium hydroxide alone. According to Jin and $\mathrm{He}$, the addition of Nisin to magnesium oxide nano particles increases the antibacterial properties of magnesium oxide. While the addition of zinc oxide nanoparticles to magnesium oxide nanoparticles does not alter material properties against Eschrichia coli14. In a study by Jia et al., SiO2 nanoparticles coated with silver and zinc particles had antibacterial properties higher than silver coated with $\mathrm{SiO} 2$ nanoparticles alone31. According to Mclean et al., the combination of silver and copper on different carriers, had higher anti-bacterial properties than copper and silver alone. ${ }^{28}$ Similar to the results of this study, other studies also confirm the presence of synergistic properties between metal particles. These effects may be due to application of antibacterial effects in different ways individually by each particle or due to composition obtained from the particle combinations. ${ }^{26-}$ ${ }^{28,32}$ In conclusion, the use of metal nanoparticles is effective on the extent of the inhibition zone caused by calcium hydroxide. In the concentrations used, copper nanoparticles had higher properties than silver nanoparticles at similar concentrations. The combination of silver particles with copper, magnesium oxide, or zinc oxide significantly increased the inhibition zone diameter of silver, indicating synergy among particles.

\section{List of acronyms}

PPM - parts per million

MTA - mineral trioxide aggregate

SPSS - Statistical Package for the Social Sciences

BHI - Brain heart infusion

PTCC - Persian type culture collection

\section{Author's contributions}

Each author contributed in equal part to the manuscript.

\section{Acknowledgments \\ Funding: None.}

\section{Conflict of Interest}

The authors declare no conflicts of interests.

\section{Ethical Publication Statement}

We confirm that we have read the Journal's position on issues involved in ethical publication and affirm that this report is consistent with those guidelines.

\section{Corresponding Author}

Dr Mohsen Aminsobhani, Dental School, AJA University of Medical Sciences, Tehran, Iran.

Email: maminsobhani@yahoo.com

E-mail of co-authors

Hazhir Yousefshahi: h.yshahi@yahoo.com Mehdi Shokri: mehdyshokri@gmail.com

Razieh Shahbazi: shahbazyrazieh@yahoo.com

\section{References}

1. Siqueira JF. Endodontic infections: concepts, paradigms, and perspectives. Oral Surg Oral Med Oral Pathol Oral Radiol Endod 2002;94:281-93.

2. Byström A, Claesson R, Sundqvist G. The antibacterial effect of camphorated paramonochlorophenol, camphorated phenol and calcium hydroxide in the treatment of infected root canals. Endod Dent Traumatol 1985;1:170-5.

3. Byström A, Sundqvist G. Bacteriologic evaluation of the efficacy of mechanical root canal instrumentation in endodontic therapy. Scand $\mathbf{J}$ Dent Res 1981;89:321-8.

4. Silva LAB, Nelson-Filho P, Leonardo MR, Rossi MA, Pansani CA. Effect of calcium hydroxide on bacterial endotoxin in vivo. J Endod 2002;28:94-8.

5. Tanomaru Filho M, Leonardo MR, da Silva LAB. Effect of irrigating solution and calcium hydroxide root canal dressing on the repair of apical and periapical tissues of teeth with periapical lesion. $\mathbf{J}$ Endod 2002;28:295-9.

6. Haapasalo H, Siren E, Waltimo T, Orstavik D, Haapasalo M. Inactivation of local root canal 
medicaments by dentine: an in vitro study. Int Endod J.2000;33:126-31.

7. Portenier I, Haapasalo H, Rye A, Waltimo T, Ørstavik D, Haapasalo M. Inactivation of root canal medicaments by dentine, hydroxylapatite and bovine serum albumin. Int Endod J 2001;34:184-8.

8. Afkhami F, Pourhashemi SJ, Sadegh M, Salehi Y, Fard MJK. Antibiofilm efficacy of silver nanoparticles as a vehicle for calcium hydroxide medicament against Enterococcus faecalis. J Dent 2015;43:1573-9.

9. Samiei M, Aghazadeh M, Lotfi M, Shakoei S, Aghazadeh Z, Vahid Pakdel SM. Antimicrobial efficacy of mineral trioxide aggregate with and without silver nanoparticles. Iran Endod J 2013;8:166-70.

10. Javidi M, Afkhami F, Zarei M, Ghazvini K, Rajabi O. Efficacy of a combined nanoparticulate/calcium hydroxide root canal medication on elimination of Enterococcus faecalis. Aust Endod J 2014;40:61-5.

11. Fuss Z, Mizrahi A, Lin S, Cherniak O, Weiss E. A laboratory study of the effect of calcium hydroxide mixed with iodine or electrophoretically activated copper on bacterial viability in dentinal tubules. Int Endod J 2002;35:522-6.

12. Knappwost A. Das Depotophorese-Verfahren mit Kupfer-Calciumhydroid, die zur systematischen ausheilung fuhrende alternative in dir endodontie. Das Deutsche Zahnärzteblatt 1993:102;618-628

13. Sawai J, Kojima H, Igarashi H, Hashimoto A, Shoji S, Sawaki T, et al. Antibacterial characteristics of magnesium oxide powder. World J Micro Bio 2000;16:187-94.

14. Jin T, He Y. Antibacterial activities of magnesium oxide (MgO) nanoparticles against foodborne pathogens. J Nano Res 2011;13:6877-85.

15. Sawai J. Quantitative evaluation of antibacterial activities of metallic oxide powders $(\mathrm{ZnO}, \mathrm{MgO}$ and $\mathrm{CaO}$ ) by conductimetric assay. J Microbiol Methods 2003;54(2):177-82.

16. Aydin Sevinç B, Hanley L. Antibacterial activity of dental composites containing zinc oxide nanoparticles. J Biomed Mater Res B Appl Biomater. 2010;94:22-31.

17. Holister P, Weener J-W, Román C, Harper T. Nanoparticles. Technology White Papers 2003;3:1-11.

18. Li P, Li J, Wu C, Wu Q, Li J. Synergistic antibacterial effects of $\beta$-lactam antibiotic combined with silver nanoparticles. Nanotechnology 2005;16:1912.

19. Ruden S, Hilpert K, Berditsch M, Wadhwani P, Ulrich AS. Synergistic interaction between silver nanoparticles and membrane-permeabilizing antimicrobial peptides. Antimicrob Agents Chemother 2009;53:3538-40.
20. Yan H, Hancock RE. Synergistic interactions between mammalian antimicrobial defense peptides. Antimicrob Agents Chemother 2001;45:1558-60.

21. Gomes B, Souza S, Ferraz C, et al. Effectiveness of $2 \%$ chlorhexidine gel and calcium hydroxide against Enterococcus faecalis in bovine root dentine in vitro. Int Endod J 2003;36:267-75.

22. Lynne RE, Liewehr FR, West LA, Patton WR, Buxton TB, McPherson JC. In vitro antimicrobial activity of various medication preparations on $\mathrm{E}$. faecalis in root canal dentin. J Endod 2003;29:18790

23. Turk BT, Sen BH, Ozturk T. In vitro antimicrobial activity of calcium hydroxide mixed with different vehicles against Enterococcus faecalis and Candida albicans. Oral Surg Oral Med Oral Pathol Oral Radiol Endod 2009;108:297-301.

24. 24Huang L, Li D, Lin Y, Evans DG, Duan X. Influence of nano-MgO particle size on bactericidal action againstBacillus subtilis var. niger. Chin Sci Bull 2005;50:514-9.

25. Morones JR, Elechiguerra JL, Camacho A, et al. The bactericidal effect of silver nanoparticles. Nanotechnology 2005;16:2346.

26. Top A, Ülkü S. Silver, zinc, and copper exchange in a Na-clinoptilolite and resulting effect on antibacterial activity. App Cl Sci 2004;27:13-9.

27. Du W-L, Niu S-S, Xu Y-L, Xu Z-R, Fan C-L. Antibacterial activity of chitosan tripolyphosphate nanoparticles loaded with various metal ions. Carbo Poly 2009;75:385-9.

28. McLean RJ, Hussain A, Sayer M, Vincent PJ, Hughes DJ, Smith TJ. Antibacterial activity of multilayer silver-copper surface films on catheter material. Can J Mic. 1993;39:895-9.

29. Inoue Y, Kanzaki Y. The mechanism of antibacterial activity of silver-loaded zeolite. J Inorg Bioch 1997; 67:377.

30. Gomes BPFdA, Ferraz CCR, Vianna ME, et al. In vitro antimicrobial activity of calcium hydroxide pastes and their vehicles against selected microorganisms. Braz Dent J 2002;13:155-61.

31. Jia H, Hou W, Wei L, Xu B, Liu X. The structures and antibacterial properties of nano-SiO2 supported silver/zinc-silver materials. Dent Mater 2008;24:244-9.

32. Ghosh S, Goudar V, Padmalekha K, Bhat S, Indi $\mathrm{S}$, Vasan H. ZnO/Ag nanohybrid: synthesis, characterization, synergistic antibacterial activity and its mechanism. RSC Adv 2012:2; 930-40.

Submission: May 07, 2018,

Acceptance: May 29, 2018 